e-ISSN: 2549-9122

\title{
Peran Guru PAI dalam Meningkatkan Karakter Siswa \\ Oleh:
}

Ahmad Shidqi Dian Arifandi

Email: ashidqi616@gmail.com

Universitas Bondowoso, Indonesia

\begin{abstract}
Abstrak
. ’.Tujuan Penelitian Untuk mengetahui bentuk-bentuk pembelajaran Pendidikan Agama Islam dalam mengembangkan pendidikan karakter. Guna Untuk mengetahui ninilai-nilai pendidikan karakter. Penelitian ini terfokus pada peran Guru PAI dalam mengembangkan karakter siswa disekolah, dengan menggunakan pendekatan kualitatif. orang yang beriman mempunyai tandatanda yang menunjukkan bahwasanya orang tersebut beriman kepada Allah. Ketika manusia mempunyai iman yang kuat maka manusia itu akan selalu berperilaku agamis dimana tidak bertentangan dengan nilai dan norma yang berlaku di masyarakat, sehingga akan terbentuk karakter yang baik di masyarakat. Guru sebagai suri tauladan atau contoh yang baik bagi anak didiknya sekaligus sebagai pembimbing, fasilitator, kordinator, dan motivator sehingga peserta didik menjadi manusia dewasa yang dapat membawa hatinya untuk mendekatkan diri kepada Allah SWT, dan menjalankan segala perintahNya.
\end{abstract}

Keywords: Peran gur, PAI, Relegius 


\section{Pendahuluan}

Pendidikan karakter bukanlah gagasan baru, sebenarnaya eksistensi pendidikan karakter besamaan itu sendiri. Sepanjang sejarah diseluruh dunia pendidikan memiliki dua tujan besar, yaitu membantu anak anak menjadi pandai dan membantu anak anak menjadi abaik. ${ }^{1}$

Tidak terlalu berlebihan jika jika dikatakan bahwa pendidikan menjadi fondasi bagi terbentuknya ke pribadian dan karakter. Kebokbrokan moral dalam kehidupan dapat dicari akar penyebabnya dalam pendidikan. Kesalahan orientasi pendidikan dapat menyebabkan kelulusan yang hanya memiliki kecerdasan otak, namun tidak mempunyai kemuliaan watak.selama ini pendidikan menitikberatkan pada pengisian kognitif. Sementara, sisi efektif-emosional dan kecerdasa spiritual kurang diperhatikan dan seolah tidak menjadi garapan pendidikan. Masyarakat lebih menganggap bahwa orang yang cerdas adalah meraka yang mampu menghafal banyak rumus matematika, menguasai bahasa asing dengan fasih, dan mampu menjawab soal pelajaran kelas secara tepat dan cermat. Akibatnya, dunia pendidikan hanya memproduksi orang-orang yang cerdas otak. $^{2}$

Pendidikan diakui sebagai salah satu alternatif dalam mengembangkan potensi dan skill anak didik agar mampu menghadapi tantangan zaman, baik



Desain Relasi Efektif Guru Dan Murid.

Buku biru sampangan Gg.perkutut No.325-B.

Cetakan pertama. Hal.5 yang menyangkut penguasan materimateri akdemis maupun sosial kemasyarakatan. Sebagai generasi bangsa, anak didik diharapkan mampu mengembangkan potensi dirinya supaya bisa melakukan perubahan untuk masa depan bangsanya ${ }^{3}$

Seiring berjalannya waktu, konsensus yang mendukung program berjalannya pendidikan karakter gaya lama mulai runtuh. Hal ini terjadi akibat beberapa kekuatan besar. Darwinisme mengatakan bahwa kehidupan biologis merupakan produk evolusi, pandangan inilah yang kemudian memadu masyarakat dalam melihat hal-hal lain, termasuk moralitas, sebagai sesuatu yang berevolusi dan bukan suatu yang pasti dan kekal. Teteori relativitas enstein, meski hanya bermaksud menjelaskan perilaku materi fisik, juga turut memengaruhi fikiran banyak orang yang mulai berfikir, "semuanya relatif tergantung sudut pandang anda".

Moralitas sangat berhubungan dengan relasi cara orang memperlakukan, dalam sebuah komonitas kecil seperti sebuah kelas para siswa mempunyai dua macam hubungan, hubungan mereka sama guru dan sesama siswa kedua hubungan ini berpotensi melahirkan dampak positif dan negatif terhadap perkembangan karakter siswa.

Guru memiliki wewenang untuk memengaruhi nilai dan karakter anakanak setidaknya dengan tiga macam cara, yang pertama guru dapat menjadi pengasuh yang efektif mengasihi dan menghormati siswa, membantu siswa meraih keberhasilan disekolah, membangun hargadiri siswa dan membantu siswa merasakan moralitas

3 Ahmad Tafsir. 2013. Ilmu Pendidikan Islam. Bandung.

ROSDAKARYA. Cetakakan ke I hal.33 
yang sesungguhnya dengan mengamati bagaimana guru cara memperlakukan mereka

Yang kedua guru dapat menjadi tauladan pribadi yang baik yang menunjukkan sikap hormat dan bertanggung jawab baik didalam dan diluar lingkungan sekolah, guru juga dapat menjadi tauladan dalam masalah karakter dan penalaran moral melalui reaksi yang mereka berikan terhadap peristiwa-peristiwa kehidupan baik diluar dan didalam lingkungan sekolah.

Ketiga dapat menjadi seorang pembimbing memberikan pengajaran karakter melalui penjelasan, cerita dan diskusi, menunjukkan semangat pribadi dan memberikan rangsangan terhadap anak didik agar anak didik mampu mengikuti karaktersi guru dengan baik dan merealisasikan dalam kehidupan sehari-hari.

Mungkin jika hanya sekedar menyampaikan ilmu pengetahuan, semua orang bisa melakukannya. Akan tetapi, menjadi guru yang sukses mendidik muridnya insan yang bermoral dan menjadi faforit murid-muridnya, tentulah bukan hal mudah. Untuk menjadi guru yang sukses mendidik murid-muridnya, seorang guru harus bisa menjalin hubungan yang dekat dengan anak didik, baik secara fisik maupun batin. Selain itu, seorang guru harus dapat membangun suasana yang menyenangkan didalam kelas, dapat berperan sebagai "orang tua", menjadi motifator, menjadi sahabat dalam belajar, menjadi pribadi yang layak ditiru dan lain sebagainya. ${ }^{4}$

Peserta didik sebagai individu manusia memiliki sejumlah kemampuan (ability). Kemampuan ini ada yang

4 Akhmad Muhaimin Azzet, 2011.

Menjadi Guru Faforit. Jogjakarta. ARRUZZ MEDIA. Cet ke I hal.5 bersifat potensial atau kemampuan potensial atau kapasitas (capacity) dan ada yang sudah merupakan kecakapan nyata (achivemen) yang dalam hal ini disingakat kecakapan saja. Kapasitas seringkali dibedakan pula antara kapasitas umum dan kecerdasan, intelegensi dan kapasitas khusus yang sering juga disebut bakat. Dewasa ini

Selama ini strategi untuk melakukan pendidikan karakter hanya mengandalkan pendidikan agama disekolah. Pendapat ini benar, tapi belum cukup. Pendidikan karakter sesungguhnya melibatkan pendidikan moral, pendidikan nilai dan pendidikan agama. Pendidikan moral berfungsi sebagai dasar bagi sebuah pendidikan karakter, berupa keputusan moral individual, yakni apakah ia akan menjadi manusia yang baik atau yang buruk, berkaitan dengan batin seseorang , berupa keputusan, pilihan yang bebas dan tanggung jawab. Selanjutnya pendidikan nilai berkaitan dengan nilainilai budi pekerti, tatakrama, sopan santun dalam masyarakat dan akhlak, berfungsi bagi peserta didik mengenal, menyadari pentingnya dan menghayati nilai-nilai yang pantas dan semestinya dijadikan panduan bagi sikap dan perilaku manusia, baik secara perorangan maupun bersama-sama dalam suatu masyarakat. Sementara itu, pendidikan agama berfungsi sebagai fondasi yang lebih kokoh, kemantapan paling luhur, kekayaan paling tinggi dan sumber kedamaian manusia paling dalam, mempersatukan dirinya dengan realitas terakhir yang lebih tinggi, yaitu Allah sang pencipta menjadi fondasi kehidupan mereka. ${ }^{5}$

${ }^{5}$ Prof.Dr.H.Abuddin Nata, 2013.

Kapita Selekta Pendidikan Islam. Jakarta.

PT Raja Grafindo persada. Cet ke 2.hal.176 
Sudah populer di indonesia bahwa tujuan pendidikan nasional pada khususnya dan pembangunan pada umumnya adalah ingin menciptakan "manusia seutuhnya". Maksudnya manusia yang lengkap, selaras, serasi dan seimbang perkembangan semua segi kepribadian. Siapa yang dikatakan manusia utuh itu? Yang dikataan manusia utuh adalah individu-individu manusia, bukan kelompok. Sehingga manusia seutuhnya itu adalah personal atau individu-individu yang mampu menjangkau segenap hubungan dengan tuhan dengan lingkungan alam sekeliling dalam manusia lain dalam suatu kehidupan sosial yang konstruktif dan dengan dirinya sendiri. Personal atau individu yang demikian pada dirinya terdapat suatu kepribadian terpadu baik unsur akal pikiran, perasaan, moral dan keterampilan (cipta, rasa dan karsa), jasmani maupun rohani, yang berkembang secara penuh. Integrasi dari perkembangan itulah yang akan mewujudkan manusia utuh sebagai tujuan pendidikan bangsa indonesia. ${ }^{6}$

Perbaikan moral yang menjadi tujuan setiap lembaga pendidikan tidak pernah lepas dari peran seorang pemandu. Dalam hal ini pemandu yang ada dalam Sekolah adalah sosok seorang Guru. Seorang Guru diharapkan mampu melahirkan generasi penerus bangsa dengan moral yang sesuai degan ajaran Islam. Untuk membentuk moral peserta didik yang baik tentu membutuhkan profesioanalisme dan ketelatenan seorang Guru. Profesionalime ini akan mudah disalurkan apabila Guru memberikan tauladan yang baik. Sementara ketelatenan seorang guru akan

\section{${ }^{6}$ Sardiman, 2011. Interaksi Dan}

Motivasi Belajar Mengajar.Jakarta. PT

RajaGrafindo Persada. Cet ke 20. Hal 118 melahirkan semangat belajar bagi Siswanya. Semisal di lembaga SMA Negeri I Arjasa Sumenep, yang memiliki kuantitas Siswa yang tinggi dengan latar belakang lingkungan sosial yang berbeda. Dalam hal ini dibutuhkan seorang interpreoner yang mampu mengubah Siswa-siswa nya dengan latar belakang Siswa yang berbeda tersebut.

SMA Negeri I Arjasa Sumenep ini adalah lembaga Sekolah Menengah Atas yang ada di daerah Kepulauan kangean. Hal ini berarti lingkungan Sekolah tersebut sudah dipastikan berbanding balik terhadap lingkungan Sekolah yang ada dalam naungan pesantren dan lingkungan sekolah perkotaan, tapi hal ini tidak menjadi alasan bagi siswanya tidak memiliki perilaku yang baik, yang sesuai dengan kaidah-kaidah islam, apalagi dengan didukung dengan kegiatan keagamaan (Religius) yang dilanksanakan setiap minggu, seperti: kegiatan ROHIS (Rohani Islam) dan kegiatan-kegiatan Osis yang edentik dengan keagamaan, misalnya: pengajian yang dilaksanakan setiap mingggu sebagai kegiatan rutinitas. Tidak hanya sampai disitu, SMA Negeri I Arjasa sumenep selain meliki profil yang baik tentang pembentukan karakter dalam bidang keagamaan juga ada kegiatan yang menjadi proiritas dalam membentuk karakter yang baik, seperti: Pencinta Alam (PA), pencinta alam merupakan salah satu bentuk kegiatan yang mendidik Siswa agar menjadi siswa yang peduli terhadap lingkungan., Upacara Bendera. Sering kali kita temui di sekolah-sekolah lain, bahwa upacara merupakan program atau kegiatan yang direkomendasikan oleh pemerintah untuk setiap jenjang pendidikan dari SD sampai dengan SMA bahkan perguruan tinggi saban hari senin wajib melaksanakan Upacara bendera, artinya tidak hanya dilaksanakan oleh SMA 
Negeri I Arjasa sumenep, tapi kadang tidak dijadikan alasan untuk membentuk karakter siswa yang baik. Di SMA Negeri I Arjasa sumenep yang merupakan sekolah unggulan di kepulauan hal dimamfaatkan untuk mengembangkan karakter yang baik, bagaiman tidak, setiap hari senin semua Siswa tidak terrkecuali tenaga pendidik wajib melaksanakan Upacara bendera, disamping diwajibkan juga tidak kalah penting adalah pelasanaan upacara pada pukul 06.00 WIB, jadi siswa dan para pendidik haru dating kesekolah pada jam 05.30 WIB guna untuk mendidik kedisiplinan pada siswa-siswi sehingga menjadikan siswa-siswi yang mempunya karakter yang baik.

Lingkungan Sekolah yang kondusif guna membentuk karakter Siswa yang baik sudah barang tentu sangatlah mendukung. Hanya saja factor motivasi dari dalam sekolah sangat dibutuhkan. Lebih-lebih peranan seorang Guru. Kaidah umum bahwa lingkungan merupakan factor yang memiliki peranan krusial dalam membentuk karakter. Begitupun seorang Guru. Hanya saja dalam konteks ini Guru tidak terlalu tersibukkan untuk membentuk karakter peserta didik, karena lingkungan sudah membentuknya. Guru memiliki peran untuk mengkristalkan dan menjaga karakter siswa yang sudah baik, sehingga peneliti penting untuk memberikan kajian terkait dengan "Peran Guru PAI dalam Meningkatkan Karakter Siswa Di SMA Negeri I Arjasa Sumenep tahun pelajaran 2016/2017”.Tujuan Penelitian Untuk mengetahui bentuk-bentuk pembelajaran Pendidikan Agama Islam dalam mengembangkan pendidikan karakter. Guna Untuk mengetahui ninilai-nilai pendidikan karakter di SMA Negeri I Arjasa Sumenep.

\section{Kajian Konseptual}

Sebelum kami membahas tentang pendidikan karakter, peneliti suadah memnemukan artikel yang berkaitan dengan pendidikan karakter yaitu: penelitian yang berjudul

\section{Peranan Motivasi Guru PAI dalam} Meningkatkan Karakter Siswa Di SMA Mambaul Ulum Arjasa Sumenep". yang disusun oleh Sueb, mahasiswa fakultas tarbiyah PAI, dalam skripsi tersebut diuraikan bagaimana guru melakukan segala aktifitas sehingga dapat menjadikan peserta didik mepunyai karakter yang baik, bahwa pendidikan karakter itu harus dilakukan secara utuh dan menyeluruh, mulai dari jenjang pendidikan yang paling rendah sampai pada yang paling tinggi, dalam pendidikan formal guru dalam melakukan upaya pendidikan karakter $25 \%$ selebihnya ditentukan oleh jalur pendidikan yang lain, baik itu melalui jalur pendidikan formal atau non formal.

2. Artikel yang berjudul Pengaruh guru agama dalam meningkatkan moralitas siswa di SMA I Situbondo tahun ajaran 2012/2013, yang ditulis oleh Izul Madid. Dalam skripsi tersebut di uraikan bahwa secara umum Guru agama dalam sekolah tersebut memang menjadi panutan moralitas yang baik bagi seluruh komponen sekolah lebihlebih pada siswanya.

Dalam Penelitian tersebut juga dijelaskan bahwa ada dua hal yang sangat mempengaruhi terhadap upaya perbaikan karakter dilembaga tersebut, yakni adanya sebuah kebebasan dalam mengadakan kegiatan keagamaan dan adanya kometmen bersama dan uswah(contoh) dari semua guru lebihlebih guru agama itu sendiri. 
Dari dua pembahasan skripri tersebut hanya difukuskan kepada motivasi guru agama dan peningkatan moral secara umum, sehingga dianggap perlu untuk membahas secara khusus dan fokus tentang guru agama dalam mengembangkan karakter siswa untuk mengetahui sejauh mana peran guru PAI dalam mengembangkan karakter siswa.

\section{Metode}

Penelitian ini terfokus pada peran Guru PAI dalam mengembangkan karakter siswa disekolah, dengan menggunakan pendekatan kualitatif. Bogdan dan Taylor mendefinisikan pendekatan/metode penelitian kualitatif sebagai prosedur penelitian yang menghasilkan data deskriptif berupa kata-kata tertulis atau lisan dari orangorang dan perilaku yang dapat diamati. Menurut mereka, pendekatan ini diarahkan pada latar dan individu tersebut secara holistik. ${ }^{7}$

1. Jenis Penelitian

Dalam hal ini jenis penelitian yang digunakan adalah kualitatif deskriptif. Menurut Lexy J. Moleong, data yang dikumpulkan dalam deskriptif ini adalah berupa kata-kata, gambar, dan bukan angka-angka. Hal itu disebabkan oleh adanya penerapan metode atau pendekatan kualitatif. Selain itu, semua yang dikumpulkan berkemungkinan menjadi kunci terhadap apa yang sudah diteliti. ${ }^{8}$

\section{A. Kehadiran Peneliti}

Peneliti hadir di lembaga SMA Negeri I Arjasa Sumenep , pertama kali peneliti akan mendatangi kepala sekolah (Drs.Sulaiman) untuk

\footnotetext{
${ }^{7}$ Lexy J. Moleong, 2012. Metodologi penelitian kualitatif. Bandung: PT Remaja Rosdakarya. Cet. Ke-30, hal.4 ${ }^{8}$ Ibid., h. 11
}

memberitahukan dan meminta izin penelitian, untuk meneliti tentang "Peran Guru PAI dalam mengembangkan karakter siswa di SMA Negeri I Arjasa Sumenep tahun pelajaran 2016/2017”. Setelah itu peneliti akan mendatangi bagian tata usaha dan kaur kurikulum untuk memberikan surat tugas penelitian agar dijadikan arsip di ruang tata usaha. Selanjutnya peneliti melaksanakan penelitian sebagaimana mestinya di SMA Negeri I Arjasa Sumenep

\section{B. Lokasi Penelitian}

SMA Negeri I Arjasa merupakan salah satu lembaga formal yang berada di kepulauan kangean kabupaten sumenep.

\section{Pembahasan}

Dalam pembahasan ini peneliti akan menjelaskan tentang data-data yang diperoleh melalui wawancara yang didapat dari lembaga SMA Negeri I Arjasa sumenep. Oleh sebab itu, untuk menvalidkan data-data lapangan tersebut di bawah ini peneliti akan memaparkan perpaduan sebagian teori-teori yang diyakini relevan dengan fakta yang ada dilapangan sebagaimana teori-teori tersebut telah di dibangun di bab II.

1. Peran guru PAI dalam mengembangkan karakter siswa di SMA Negeri I Arjasa sumenep.

Peran guru PAI di SMA Negeri I Arjasa sumenep sebagai aktor utama dalam mengembangkan karakter siswa di sekolah sangatlah besar sekali, guru sebagai pengajar di sekolah harus bisa mendidik, membina, dan memberikan suri tauladan kepada siswa-siswinya dengan baik. Hal ini selaras dengan peryataan Zakiyah Daradjat bahwa peran guru PAI yaitu membina 
dan mengasuh peserta didik agar senantiasa dapat memahami ajaran Islam secara menyeluruh (kaffah). ${ }^{9}$ Hal ini juga selaras dengan peryataan Syaiful Bahri Djamarah tentang peran guru sebagai berikut:

a.Korektor, berarti guru berhak menilai dan mengoreksi sikap, tingkah laku dan perbuatan siswa, sikap dan perbuatan ini dipengaruhi oleh nilai-nilai yang melekat pada diri siswa.

b. Inspirator, berarti guru dituntut untuk memberikan petunjuk tentang bagaimana cara belajar yang baik, petunjuk tersebut dapat bertolak dari pengalaman atau pengetahuan yang telah didapat oleh guru sehingga mampu untuk memecahkan problematika yang dihadapi siswa.

c.Informator, berarti guru harus memberikan informasi tentang perkembangan sains dan teknologi, selain sejumlah bahan pelajaran untuk setiap mata pelajaran yang telah diprogramkan oleh guru.

d. Organisator, berarti guru memiliki kegiatan pengelolaan aktifitas akademik, menyusun tata tertib kelas, menyusun kalender akademik dan sebagainya.

e.Motivator, berarti guru harus memotivasi siswa agar bergairah dan aktif dalam belajar.

f. Inisiator, berarti guru menjadi pencetus ide-ide progresif dalam pendidikan sehingga prosesnya tidak ketinggalan zaman dan mengalami perkembangan yang

\footnotetext{
${ }^{9}$ Heri Gunawan, 2012, Kurikulum dan Pembelajaran Pendidikan Agama Islam, Alfabeta Bandung, cet-1, Hal .201
}

lebih baik dari keadaan sebelumnya.

g. Fasilitator, berarti guru menyediakan fasilitas belajar sehingga dapat tercipta lingkungan belajar yang menyenangkan siswa dan memudahkan aktivitas belajar mereka.

h. Pembimbing, berarti kehadira guru di sekolah adalah untuk membimbing siswa menjadi manusia dewasa yang berprilaku secara mandiri, awalnya siswa tergantung pada bantuan guru karena kekurangmampuannya. Namun dengan bimbingaan guru, rasa ketergantungan tersebut semakin berkurang dikerenakan tingkat kedewasaan telah berkembang sehingga nantinya mampu berdiri sendiri (mandiri) dalam belajar.

i. Demonstrator, brarti guru harus memperjelas penjelasannya melalui peragaan alat dang gerak-gerak ritme tubuh sehingga memudahkan pemahaman siswa, dengan demikian guru dapat membantu pemperjelas pemahaman siswa sehingga diharapkan kesejalanan antara keinginan guru dan pemahaman siswa dan diantara mereka tidak terjadi salah pengertian.

j. Pengelolaan kelas, berarti guru berperan dalam pengelola proses pembelajaran. Ia hendaknya mengatur penempatan masingmasing siswa sesuai dengan proporsinya, menjadi dari kegaduan dan membuat suasana kelas semakin menyenangkan sehingga aktivitas mengajar semakin optimal.

k. Mediator, berarti guru harus memiliki pengetahuan dan 
pemahaman yang cukup terhadap pengguanaan berbagai jenis media pendidikan sebagai alat komunikasi yang efektif dalam proses belajar mengajar shingga dapat membantu memperjelas eksplanasi dan sebagai jalan pemecahan masalah.

1. Supervisor, berarti guru harus membantu memperbaiki dan menilai secara kritis terhadap proses pembelajaran.

$\mathrm{m}$. Evaluator, berarti guru bertugas menilai aspek-aspek intrinsic (kepribadian) dan ekstrinsik yang mengarah kepada pencapaian prestasi verbal siswa. ${ }^{10}$ Dan diperkuat oleh Adam dan Dickey bahwa peran guru adalah sebagai pengajar, pembimbing, ilmuan, pribadi, penghubung, modernisator, dan pembangun. ${ }^{11}$

Adapun peran guru PAI yang diterapkan dalam mengembangkan karakter siswa adalah memberi tambahan kegiatan-kegiatan keagamaan di sekolah dan di luar sekolah. Memberi tambahan kegiatankegiatan keagamaan di sekolah dan di luar sekolah merupakan salah satu cara dan upaya yang memang perlu dilakukan untuk mengembangkan karakter siswa di sekolah. Hal ini sangat relevan dengan pernyataan William Benner yang dikutip oleh Syamsul kurniawan, bahwa sekolah memiliki peran yang sangat penting dalam pendidikan karakter seorang peserta didik. Apalagi bagi peserta

${ }^{10}$ Syaiful Bahri Djamarah, 2000,

Guru dan Anak Didik dalam Interaksi

Edukatif, Reneka Cipta Jakarta, hal 43-48

${ }^{11}$ Oemar Hamalik, 2014, proses

belajar mengajar, PT Bumi Aksara, cet-16.

Hal. 123-124 didik yang tidak mendapatkan pendidikan karakter sama sekali dilingkungan dan keluarga mereka. Apa yang dikemukakan benner, tentu saja bukan tanpa dasar, melaainkan dengan hasil penelitiannya tentang kecenderungan masyrakat di Amirika, dimana anak-anak lebih banyak menghabiskan waktu disekolah keting dirumah mereka. William Benner sampai pada kesimpulan bahwa apa yang terekam dalam memori anak didik disekolah, ternyata memiliki pengaruh yang sangt besar bagi kepribadian atau karakter mereka kelak ketika sudah dewasa. Ringkasnya, sekolah merupakan salah satu wahana efektif dalam dunia pendidikan karakter terhadap anak didik pada saat ini. ${ }^{12}$

Selain itu untuk mengembangkan karakter di sekolah diperlukan adanya pembiasaan kepada peserta didik di SMA Negeri I Arjasa sumenep untuk proaktif di dalam mengikuti kegiatan-kegiatan keagamaan. Hal ini sesuai dengan temuan Nur Ali, dkk. Bahwah kegiatan dan praktek keagamaan yang dilaksanakan secara terprogram dan rutin di sekolah dapat menciptakan pembiasaan berbuat baik dan benar menurut ajaran agama yang diyakininya dikalangan mereka. ${ }^{13}$ Dalam model ini peserta didik berposisi sebagai objek. Jika posisi siwa sebagai objek dalam penerapan suatu model, berarti model yang diterapkan adalah model formal, model ini biasanya menggunakan cara pendekatan yang bersifat keagamaan yang normative, doktriner, dan absolutis. Peserta didik diarahkan untuk menjadi pelaku agama yang

12 Syamsul Kurniawan. 2016.

Pendidikan karakter. Ar-ruzz media

Yogyakarta. Cet.II hal. 106

${ }^{13}$ Ibid, hal 30 
loyal, memiliki sikap cometment (keperpihakan), dan dedikasi (pengabdian yang tinggi terhadap agama yang dipelajarinya).

2. Bentuk-bentuk pembelajaran Pendidikan Agama Islam dalam upaya mengembangkan karakter siswa Di SMA Negeri I Arjasa Sumenep.

Dalam pengembangan karakter di sekolah tidak hanya membutukkan seorang guru untuk memberikan arahan-araha yang lebih abaik, akan tetapi juga perlu adanya bentuk atau model pembelajaran yang dilakukan oleh seorang pendidik dalam mengembangkan karakter. Seperrti halnya yang dilakukan atau diterapkan di SMA negeri I Arjasa sumenep tentang beberapa bentuk atau model pembelajaran yang yang dilaksanaka pada saat ini. sekolah memberikan kebebasan kepada guru untuk memberikan pendidikan yang baik terhadap anak didiknya, sehingga semua guru mempunyai kesempatan untuk memberikan pelajaran yang mempunyai nilai-nilai agama, artinya tidak hanya guru agama yang mempunyai kewajiban dlam menberikan pendidikan yang mempunyai nilai-nilai agama. Akan tetapi disisi lain guru agama memnpunyai peran yang sangat signifikan sehingga guru agama menjadi tolak ukur dari sikap peserta didik. Hal ini menunjukkan bahwa model pembelajaran yang digunakan di SMA Negeri I Arjasa Sumenep adalah model Reflektif. Dalam hal ini sesuai dengan apa yang di sampaikan oleh Dharma Kesuma dkk, bahwa pembelajaran reflektif adalah pendidikan karakter yang terentegrasi/melekat pada semua bidang studi yang ada disekolah. Proses pembelajaran ini dilakukuan oleh semua guru mata pelajaran/bidang studi, seperti guru
Matematika, guru Basa Indonesia, guru IPA dan guru mata pelajaran yang lain. Proses pembelajaran reflektif dilakukan mulai dari mengaitkan materi-materi yang dibahas dalam pembelajaran dengan makna dibelakang materi tersebut. ${ }^{14}$

3. Penanaman nilai-nilai pendikan karakter di SMA Negeri I Arjasa Sumenep.

Dari apa yang dipaparkan diatas tentang beberapa peran guru PAI dan bentuk atau model pembelajaran, tidak kala pentingnya juga adalah hal-hal- yang berkaitan dengan penanaman nilai-nilai pendidikan karakter yang sangat mendukung pada perkembangan karakter peserta didik. Seperti apa yang disampaikan oleh beberapa guru SMA Negerri I Arjasa Sumenep khususnya guru PAI tentang penanaman nialai karakter pada siswa, misalnya guru PAI mengajarkan anak didiknya menghargai sesame (toleransi), menjaga kebersiahan lingkungan baik lingkungan sekolah atau lingkungan dimana siswa itu tinggal(cinta lingkungan), berbicara apa adanya (jujur), dan melakukan kegiatan keagamaan-keagamaan(religious).

Untuk menjadikan anak didik memiliki kepribadian atau karakter yang sesuai dengan rambu-rambu agama, tidak hanya mengajarkan dan memberikan contoh nilai-nilai pendikan karakter akan tetapi juga perlu diberikan penjelasan tentang makna, mamfaat dan tujuan apa yang telah dilaksanakan, dan juga perlu disampaikan tentang mamfaat ilmu yang telah diperoleh agar anak didik

\footnotetext{
${ }^{14}$ Drs.Dharma Kesuma,M.Pd, Cepi

Triatna,S.Pd.,M.Pd. dan Dr.H.Johar

Pernama,MA. Pendidikan karakter kajian teori dan praktek disekolah. PT Remaja posdakarya.hal.115
} 
tidak mudah dipengaruhi oleh orang orang yang akan menjerumuskan, sehinggga anak didik selalu bartakwa kepaada Allah SWT. Sebagaimana tercantum di dalam Al-Qur'an surat Al-Anfal ayat 1-4.

Artinya: "sesunggunya orang-orang beriman ialah mereka yang bila disebut nama Allah gemetarlah hati mereka, dan apabila dibacakan ayat-ayatnya bertambahlah iman mereka (karenanya), dan hanya kepada tuhanlah mereka bertawakkal. (yaitu) orang-orang yang mendirikan shalat dan yang menafkahkan sebagian rizki yang kami berikan kepada mereka. Itulah orang-orang yang beriman dengan sebenar-benarnya. Mereka akan memperoleh beberapa derajat ketinggihan di sisi tuhannya dan ampunan serta rizki (nikmat) yang mulia". (QS. Al-Anfal ayat: 2$4)^{15}$

Dari ayat diatas jelaslah bahwa orang yang beriman mempunyai tanda-tanda yang menunjukkan bahwasanya orang tersebut beriman kepada Allah. Ketika manusia mempunyai iman yang kuat maka manusia itu akan selalu berperilaku agamis dimana tidak bertentangan dengan nilai dan norma yang berlaku di masyarakat, sehingga akan terbentuk karakter yang baik di masyarakat.

\section{Kesimpulan}

Dari hasil penelitian mengenai
"peran guru PAI dalam
mengembangkan karaktter di SMA
Negeri I Arjasa Sumenep" maka dapat
diambil kesimpulan sebagai berikut:
1. Peran Guru Pendidikan Agama
Islam dalam menembangkan
karakter di SMA Negeri I Arjasa
sumenep adalah sebagai suri

${ }^{15}$ Al-Qur'an Transliterasi Per Kata dan Terjemah Per Kata,2011 tauladan atau contoh yang baik bagi anak didiknya sekaligus sebagai pembimbing, fasilitator, kordinator, dan motivator sehingga peserta didik menjadi manusia dewasa yang dapat membawa hatinya untuk mendekatkan diri kepada Allah SWT, dan menjalankan segala perintahNya.

2. Bentuk-bentuk pembelajaran guru Pendidikan Agama Islam dalam mengembanmgkan karakter di SMA Negeri I arjasa sumenep ialah salah satu bentuk atau model yang sangat membantu terhadap perkembangan karakter anak didik karena model yang digunakan adalah model "Reflekstif" dimana model ini tidak hanya diperankan oleh guru PAI melainkan melibatkan semua dewan guru dalam mengembangkan karakter, hanya saja guru PAI sebagai actor utama dalam pengembangan karakter peserta didik.

3. Penanaman nilai-nilai pendidikan karakter adalah salah satu usaha yang dilakukan oleh guru pendidikan agama islam dalam mengembangkan karakter,namun hal ini tdak hanya dilakukan oleh guru agama, tetapi juga dibanntu oleh pihak-pihak lain. nilai-nilai pendidikan karakter yang ada di SMA Negeri I Arjasa sumenep adalah: religius, jujur, disiplin, cinta lingkungan, toleransi, dan lain sebaginya.

\section{Daftar Pustaka}

Hosaini, H. (2020). Pembelajaran dalam era "new normal" di pondok pesantren Nurul Qarnain Jember tahun 2020. LISAN ALHAL: Jurnal Pengembangan Pemikiran dan Kebudayaan, 14(2), 361-380.

Samsudi, W., \& Hosaini, H. (2020). Kebijakan Sekolah dalam Mengaplikasikan Pembelajaran Berbasis Digital di Era 
Industri 4.0. Edukais: Jurnal Pemikiran Keislaman, 4(2), 120-125.

Mahtum, R., \& Zikra, A. (2022, November). Realizing Harmony between Religious People through Strengthening Moderation Values in Strengthening Community Resilience After the Covid 19 Pandemic. In The 4th International Conference on University Community Engagement (ICON-UCE 2022) (Vol. 4, pp. 293-299).

Hosaini, H., \& Samsudi, W. (2020). Menakar Moderatisme antar Umat Beragama di Desa Wisata Kebangsaan. Edukais: Jurnal Pemikiran Keislaman, 4(1), 1-10.

Hosaini, H. (2020). Integrasi Konsep Keislaman Yang Rahmatan Lil 'Alamin Menangkal Faham Ekstremisme Sebagai Ideologi Beragama Dalam Bingkai Aktifitas Kegiatan Keagmaan Mahasiswa Di Kampus Universitas Bondowoso. Edukais: Jurnal Pemikiran Keislaman, 3(1), 12-30.

Hosaini, H., \& Kurniawan, S. (2019). Manajemen Pesantren dalam Pembinaan Umat. Edukais: Jurnal Pemikiran Keislaman, 3(2), 82-98.

Muis, A., Eriyanto, E., \& Readi, A. (2022). Role of the Islamic Education teacher in the Moral Improvement of Learners. AtTarbiyat: Jurnal Pendidikan Islam, 5(3).

Halim, A., Hosaini, H., Zukin, A., \& Mahtum, R. (2022). PARADIGMA ISLAM MODERAT DI INDONESIA DALAM MEMBENTUK PERDAMAIAN DUNIA. JISMA: Jurnal IImu Sosial, Manajemen, dan Akuntansi, 1(4), 705-708.

Zukin, A., \& Firdaus, M. (2022). Development Of Islamic Religious Education Books With Contextual Teaching And Learning. AtTarbiyat: Jurnal Pendidikan Islam, 5(1).

Hosaini, H., Zikra, A., \& Muslimin, M. (2022). EFFORTS TO IMPROVE TEACHER'S PROFESSIONALISM IN THE TEACHING LEARNING PROCESS. Al-Risalah: Jurnal Studi Agama dan Pemikiran Islam, 13(2), 265-294.

Salikin, H., Alfani, F. R., \& Sayfullah, H. (2021). Traditional Madurese Engagement Amids the Social Change of the Kangean
Society. RETORIKA: Jurnal IImu Bahasa, 7(1), 32-42.

Hosaini, H., \& Fikro, M. I. (2021). PANCASILA SEBAGAI WUJUD ISLAM RAHMATAN LI AL-ALAMIIN. Moderation/ Journal of Islamic Studies Review, 1(1), 91-98.

Hosaini, H. (2020). Ngaji Sosmed Tangkal Pemahaman Radikal melalui Pendampingan Komunitas Lansia dengan sajian Program Ngabari di Desa Sukorejo Sukowono Jember. As-Sidanah: Jurnal Pengabdian Masyarakat, 2(1), 159-190.

Agustin, Y. D., Hosaini, H., \& Agustin, L. (2021). ANALYSIS OF THE IMPACT OF EARLY MARRIAGE ON ADOLESCENT REPRODUCTIVE HEALTH BASED ON HEALTH PERSPECTIVES AND ISLAMIC RELIGION. UNEJ e-Proceeding, 103-107.

Hosaini, H., \& Kamiluddin, M. (2021). Efektivitas Model Pembelajaran Means-Ends Analysis (MEA) dalam meningkatkan Keterampilan Komunikasi Interpersonal dan Pemecahan Masalah pada mata pelajaran Fikih. Edukais: Jurnal Pemikiran Keislaman, 5(1), 43-53.

'Amir, Najib Khalid al-, Tarbiyah Rasulullah, terj. Ibnu Muhammad dan Fakhruddin Nursyam, cet. ke-4, Jakarta: Gema Insani Press, 2000.

Hosaini, H. (2020). PEMBELAJARAN DALAM ERA "NEW NORMAL" DI PONDOK PESANTREN NURUL QARNAIN JEMBER TAHUN 2020. LISAN AL-HAL: Jurnal Pengembangan Pemikiran dan Kebudayaan, 14(2), 361-380.

Hosaini, H. (2019). Behauvioristik Basid Learning Dalam Bingkai Pendidikan Islam Perspektif AlGhazali:(Pembelajaran Berbasis Prilaku Dalam Pandangan Pendidikan Islam). Edukais: Jurnal Pemikiran Keislaman, 3(1), 23-45.

Muslimin, M., \& Hosaini, H. (2019). KONSEP PENDIDIKAN ANAK MENURUT ALQUR'AN DAN HADITS. Edupedia: Jurnal Studi Pendidikan dan Pedagogi Islam, 4(1), 67-75.

Hosaini, H., \& Erfandi, E. (2017). Studi Komparasi Konsep Pendidikan Karakter Menurut KH. Hasyim Asy'ari dan Ki Hadjar Dewantara. Edukais: 
Jurnal Pemikiran Keislaman, 1(1), 136.

Agustin, L., Rahayu, L. P., Hosaini, H., Agustin, Y. D., \& Utami, C. B. (2022). Penyuluhan Kesehatan Reproduksi pada Remaja dalam Perspektif Kesehatan dan

Hukum. DEDICATION: Jurnal Pengabdian Masyarakat, 2(2), 16-21. 